\title{
Report on the 5th Annual Martial Arts Studies Conference - "Martial Arts, Culture and Politics"
}

\author{
Jared MIRACLE*1 (D) \& John Stefania SKOWRON-MARKOWSKA 2 (D) \\ ${ }^{1}$ Independent Scholar (United States) \\ 2 University of Wroclaw (Poland)
}

Recepción: 06/06/2019; Aceptación: 17/07/2019; Publicación: 19/07/2019.

\begin{abstract}
This is a report covering the $5^{\text {th }}$ Annual Martial Arts Studies Conference, held in Orange, California (USA) on May 23-24, 2019. There were a total of six parallel sessions comprised of 44 presentations. Although the conference theme was "martial arts, culture, and politics," the thematic organization extended beyond this premise to all aspects of martial arts as a field of investigation. As a whole, the conference was impressively orchestrated and quite well attended by representatives from around the world and is notable as the first official Martial Arts Studies Research Network event to take place in North America.
\end{abstract}

Keywords: MAS; martial arts; combat sports; conferences.

\section{Informe sobre la $5^{\text {th }}$ Annual Martial Arts Studies Conference - "Martial Arts, Culture and Politics" Resumen}

Este informe trata la $5^{\text {th }}$ Annual Martial Arts Studies Conference, celebrada en Orange, California (EE. UU.), del 23 al 24 de mayo de 2019. Se desarrollaron un total de seis sesiones paralelas, compuestas por 44 presentaciones. Aunque el tema de la conferencia fue "artes marciales, cultura y política", la organización temática fue más allá y abarcó todos los aspectos de las artes marciales como campo de investigación. En general, la conferencia estuvo excepcionalmente organizada, contó con la asistencia de participantes de todo el mundo, y es destacable que este ha sido el primer evento de la Martial Arts Studies Research Network que ha tenido lugar en Norteamérica.

Palabras clave: MAS; artes marciales; deportes de combate; conferencias.

\section{Resumo da $5^{\text {th }}$ Annual Martial Arts Studies} Conference - "Martial Arts, Culture and Politics" Resumo

Este artigo apresenta um resumo sobre a $5^{\text {th }}$ Annual Martial Arts Studies Conference, que teve lugar em Orange, Califórnia, nos dias 23 e 24 de maio de 2019. Foram realizadas 6 sessões paralelas, compostas por 44 apresentações. 0 tema da conferência foi "artes marciais, cultura e políticas", mas a organização temática foi mais abrangente e abarcou todos os aspetos das artes marciais como campo de investigação. De uma forma geral, a conferência estava muito bem organizada, contando com a participação de investigadores de todo o mundo. Foi o primeiro evento da Martial Arts Studies Research Network, que teve lugar na América do Norte.

Palavras-chave: MAS; artes marciais; desportos de combate; conferências.

\section{Introduction}

The field of Martial Arts Studies has grown significantly in recent years. That growth has not been equally distributed, however, as academic involvement by North American institutions has been minimal compared with progress seen in Europe and East Asia. The $5^{\text {th }}$ Annual Martial Arts Studies Conference took steps to remedy that lack of representation by taking place in the United States, thus allowing researchers from different regions to participate. Held on May 23-24, 2019, on the Chapman University campus in Orange, California, this conference was organized by the Martial Arts Studies Research Network (MASRN) under the theme of "martial arts, Culture, and politics."

This was the first MASRN event to be situated in North America and followed on the success of four previous such conferences held at Cardiff University, United Kingdom (see e.g., Jennings, 2017; White, 2018), a peer-reviewed journal now in regular production (i.e., Martial Arts Studies, https://masjournal.org.uk) and an ambitious publishing effort through Cardiff University Press.

${ }^{*}$ E-mail: jared.miracle@gmail.com 
The international attendance was suited to the conference theme and included examinations of culture and politics as they intersect with the martial arts from a wide range of perspectives both scientific and humanistic.

\section{Proceedings}

Given that this was the first conference of its kind held in North America, the amount of activity was impressive. 44 oral presentations were given across sixteen panels and six parallel sessions. In addition, the first day began with opening remarks by primary event organizers Prof. Paul Bowman and Prof. Andrea Molle and concluded with a keynote lecture by Prof. Lauren Griffith, who discussed the intersection of capoeira as a community of practice and the larger issue of social justice through lenses of ethnicity and gender. The second day's keynote lecture by Prof. Ben Judkins concluded the conference. Prof. Judkins spoke about one of the topics included in his forthcoming book: public diplomacy and soft power as accomplished via the martial arts, particularly in the case of Chinese martial arts abroad.

The field of martial arts studies is necessarily interdisciplinary. As a result, one strength of this conference was the sheer breadth of approaches and range of material presented. Even the same styles and activities were scrutinized from quite different angles. A good example of this was the conversation around Afro-Atlantic martial arts, which saw approaches from fields as diverse as cultural politics, film studies, folklore, anthropology, and history. In keeping with this wide assortment of viewpoints, each panel followed a separate theme. Some of these themes included:

- National Masculinities

- Inventing Martial Identities

- Martial Arts in the Curriculum

- Martial Arts, Theatricality, and Performance

- Political Theory, Nationalism, Fascism and the Alt-Right

It is also worth mentioning the strong team of female researchers, including the keynote speaker, Lauren Miller Griffith $(2016 ; 2017)$. The issue of women's research on martial arts and sports and their participation in the teaching and training process was widely discussed during panels as well as conversations in the lobby. Researchers also declared further cooperation and willingness to be active in the field of women's martial arts research in the future.

Despite being a relatively small and new field of study, the number of participants was notable. Of special interest in that regard was the engagement of presenters and researchers from outside the academic profession. Writers, martial arts instructors, and other private parties made a strong showing, which illustrates martial arts studies as a conduit for breaking down the publicscholarly barrier. The availability of this type of events for people involved in the field of martial arts and sports in a different way than the scientific one is very important. Both in Europe and in the United States there is an increasing participation of the already mentioned instructors or privates who want to expand their knowledge by participating in such conferences. The atmosphere of shared scientific passion created good interaction between researchers from different fields and audiences.

That healthy level of attendance was due, in no small part, to the fine work of the organizers to minimize the cost of entry. Thanks to their efforts and the generosity of Chapman University, registration to the event itself was free, thereby paving the way for many who would not otherwise have been able to take part. Hopefully more conferences will be able to follow this precedent in the future.

To conclude, the first North American foray of the Martial Arts Research Network was a success by all accounts. By meeting in California, it is likely that first-time attendees will encourage their associates to travel for future gatherings, which will naturally increase general attention to this area of scholarship. As such, it will be most enlightening to see how the discourse continues at the $6^{\text {th }}$ Annual Martial Arts Studies Conference, to be organized by Paul Bowman, Laurent Chircop- 
Reyes, Gabriel Facal, DS Farrer, and Jean-Marc de Grave, in cooperation with the Institut de recherches Asiatiques and the Anthropology Program of the University of Guam. It will take place at the Université d'Aix-Marseille on July 22-23, 2020, under the theme of "Martial Arts, Religion, and Spirituality."

\section{Acknowledgements}

The conference has made a significant contribution to the development of scientific knowledge about martial arts and sports. The great atmosphere of the meeting was also conducive to the international exchange of thoughts during breaks and meetings between the panels. This meeting was an achievement for the Martial Arts Research Network due to the fine work of the organizing committee. Special thanks must be extended to Paul Bowman and Andrea Molle for crafting such a smooth experience. Their attention to detail and flexibility not only ensured an excellent meeting, but also directly contributed to the growth of our field.

\section{References}

Griffith, L. M. (2016). In Search of Legitimacy: How Outsiders Become Part of the Afro-Brazilian Capoeira Tradition. New York; Oxford: Berghahn Books.

Griffith, L. M. (2017). Virtually Legitimate: Using Disembodied Media to Position Oneself in an Embodied Community. Martial Arts Studies, (4), 36-45. doi: 10.18573/j.2017.10185

Jennings, G. (2017). Communicating martial arts knowledge: Conferring over a wealth of possibilities. Revista de Artes Marciales Asiáticas, 12(1), 45-49. doi: $10.18002 /$ rama.v12i1.5127

White, L. (2018). Conference Report - $4^{\text {th }}$ Annual Martial Arts Studies Conference, Cardiff University, $11-12^{\text {th }} \quad$ July $2018 . \quad$ Retrieved from https://chinesemartialstudies.com/2018/07/19/conference-report-bruce-lees-culturallegacies

\section{Author's biographical data}

Jared Miracle (USA), M.Ed., PhD., folklorist and cultural anthropologist. Unaffiliated scholar available for consultation. Specializes in social violence, folk studies, narrative, East Asia (primarily Japanology), crosscultural and transnational culture, and English language education / TESOL. E-mail: jared.miracle@gmail.com

Stefania Skowron-Markowska (poland), PhD, ethnologist and cultural anthropologist. Works as a lecturer at the Institute of Classical, Mediterranean and Oriental Philology at the University of Wroclaw, Poland. Specializes in issues related to the anthropology of Asian martial arts, contemporary reception of Chinese martial arts and teaching centers (Shaolin, Wudang, China), ethnic minorities of East Asia and South-East Asia. E-mail: stefania.skowron-markowska@uwr.edu.pl 